\title{
So You Think You Can Dance Does Dance Studies
}

\section{Kate Elswit}

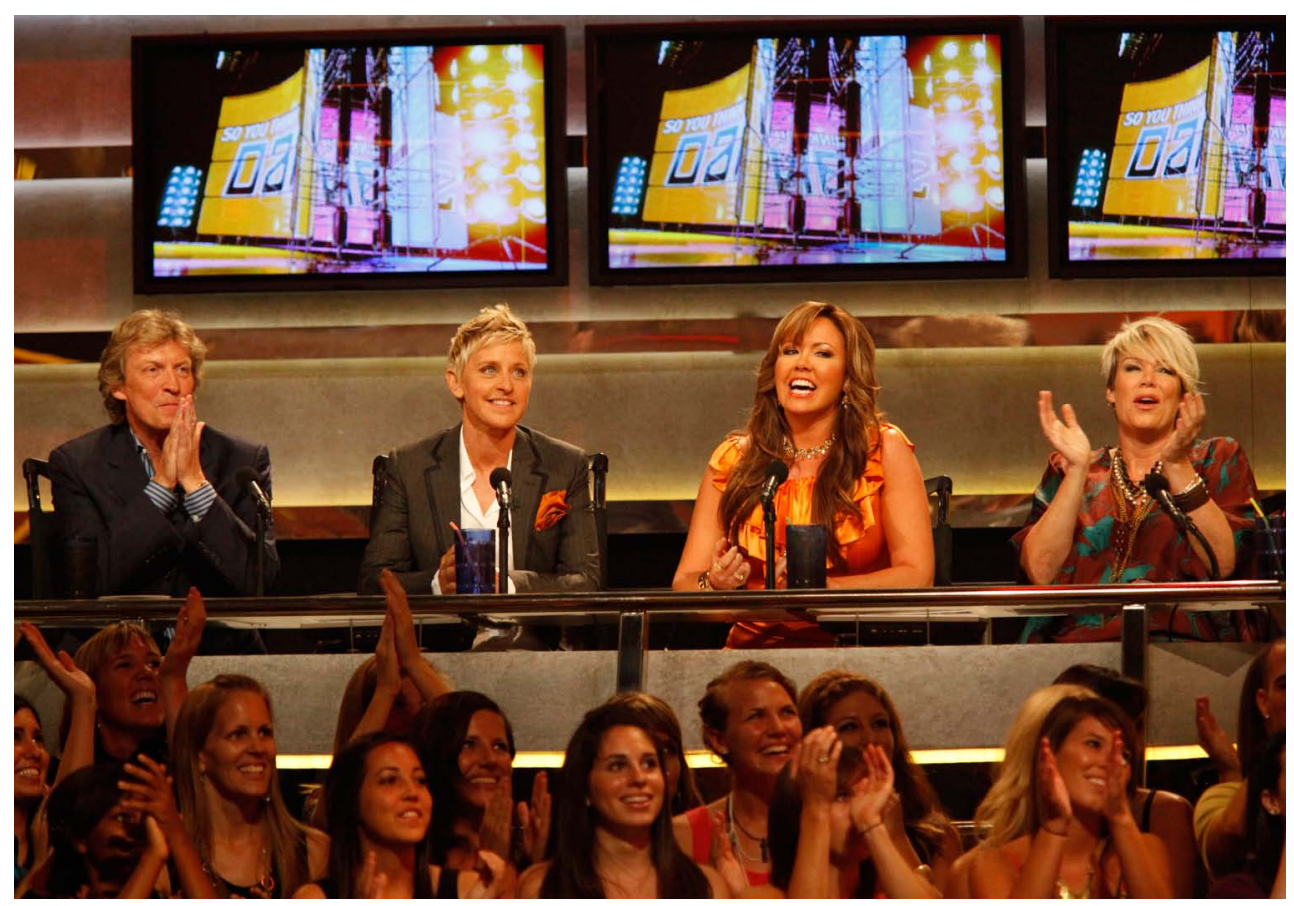

It was a perfectly adequate duet. Certainly nothing original. I have heard versions of "This Woman's Work" accompany too many lyrical, overwrought dances. There were some pretty moments of guy-lifts-girl, but they were not overwhelmingly sensational, and there was some awkward footing in the transitions. The dancers wore the standard neutral-tone attire that often accompanies the type of contemporary dance that relies on a certain sex appeal, staying in the realm of ponderous niceties but never getting too deep: his flowing shirt was unbuttoned, her legs, belly, and arms were bare. I hardly noticed the purple headscarf, except when it obscured her face. Which was why I was surprised when the first judge was so choked up that he had to deliver his response slowly, stopping to swallow hard and regain his voice, and pausing altogether a couple of times. The camera showed the female dancer of the pair and the male choreographer, both with moist eyes. By the time the third judge spoke through tears, the first had his back turned to the cameras. The fourth judge began by speaking about her father's cancer. When she broke down, the choreographer reached to cover his face.

Figure 1. Publicity photograph of the judges and studio audience. Los Angeles, first aired 22 July 2009. (Photo courtesy of FOX from So You Think You Can Dance, season 5, episode 18) 

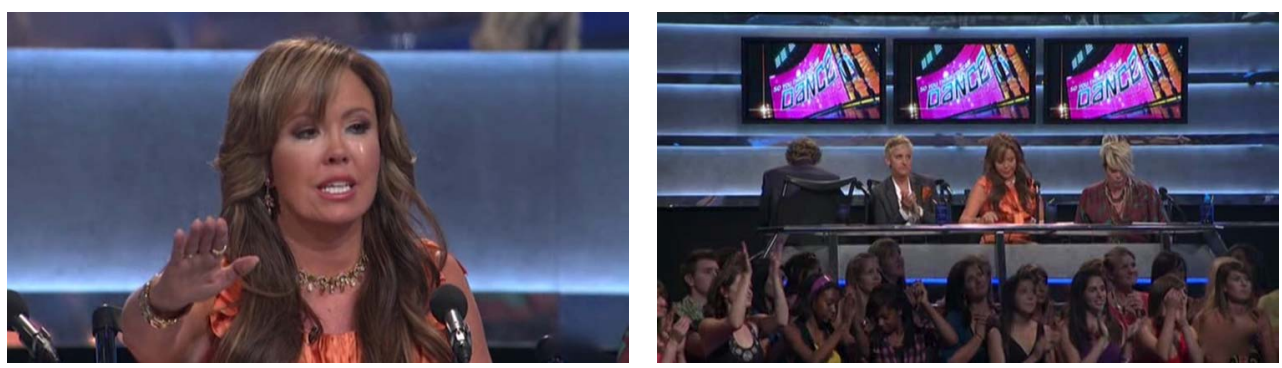

I have repeatedly watched this televised sequence from season 5, episode 18 of So You Think You Can Dance (SYTYCD), a show that builds toward the ultimate goal of crowning one performer with the explicitly subjective title "America's Favorite Dancer." I keep watching the "Cancer Dance," as bloggers often call it, because it exemplifies how, despite the show's evident emphasis on high kicks and leaps, it is not dance technique alone that is intended to "move" the show's viewers. SYTYCD's choreography typically foregrounds not just a sequence of steps but their situation within a three-act structure that allows viewers to experience dance in a way that does not privilege the movement onstage, but instead is intimately related to the fact that it is onstage. The show teaches audiences that engagement with dance is structured by dance's theatrical mechanisms, and allows for moments of strong feeling because of, rather than despite, those mechanisms.

Academic dance scholarship since the mid-1980s has had a privileged relation to "the body project," as Helen Thomas has shown, repurposing Chris Shilling's phrase for the trend under which the body has moved from the margins of academic discourse to become an industry within it (2003:11). Capitalizing on this momentum, Anglo-American studies of dance spectatorship have usually been framed in two ways: first, by critical theorization based on identity politics under which bodies materialize or challenge sociocultural constructions; and/or second, by the fuzzy term "kinesthesia," which, since dance critic John Martin's earlier elaborations of the idea, has been used to indicate that there is something particular about the embodied experience of executing or viewing movement. ${ }^{1}$ Even when kinesthetic aspects of dance were incorporated into sociocultural analysis, following the model of Ann Daly's canonical 1992 essay reworking historical dance spectatorship using feminist film theory, the capacity to affect the viewer has tended to be perceived as dependent upon the dancey-ness of dance. One response in dance studies has been to turn toward what Brian Massumi calls the paradoxical "incorporeal dimension of the body," in which movement becomes a way to understand affect and other forces that do not end at the limits of the corporeal (2002:5). So You Think You Can Dance sug-

\footnotetext{
1. The idea of kinesthetic empathy has been developed in studies that historicize the embodied experience of reception, such as Susan Foster's 2008 essay, which is elaborated in her Choreographing Empathy: Kinesthesia in Performance (2010). This essay is not meant to critique the concept, but rather to point toward SYTYCD's alternative pedagogy of reception. In this sense, I see the show more in line with German scholarship's investment in the theatricality of dance (see Siegmund 2008), but using performance that might, on the surface, not appear as readily available for such theorization.
}

Kate Elswit is a Lecturer at Stanford University and Visiting Faculty at CalArts. She previously taught at Laban and at the University of Cambridge, where she received her PhD. Her 2008 Modern Drama essay won the Sally Banes Publication Prize from the American Society for Theatre Research, and her 2009 TDR essay won the Gertrude Lippincott Award from the Society of Dance History Scholars. She has also published in Performance Research and Art Journal. Her book, Watching Weimar Dance, is forthcoming from Oxford University Press. kate@somethingmodern.org 


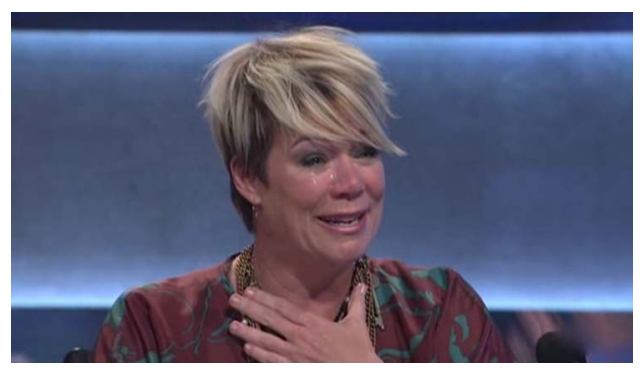

Figures 2-4. The third televised act of the extended choreography, when judges respond to the routine. From left: Mary Murphy; the full panel in situ with Nigel Lithgow's back turned; and Mia Michaels. All images from So You Think You Can Dance season 5, episode 18, first aired 22 July 2009. (Screen grabs courtesy of Kate Elswit, with permission of FOX)

gests yet another alternative to the premise that physical movement is that which moves, that is, affects or produces feeling in, dance audiences.

As André Lepecki suggests in Exhausting Dance: Performance and the Politics of Movement, there is more to dance than just motion. Lepecki challenges "dance's identity as a being-inflow," suggesting that the idea of choreography can be expanded through attention to works that reframe "the political ontology of modernity's investment on its odd, hyperkinetic being" $(2006: 1,5)$. His attention to dances that are no longer about movement holds promise for thinking about a wider range of practices, even those that involve a lot of wriggling, jumping, kicking, and shuffling. SYTYCD exploits that promise, teaching audiences how to feel dance but - if you look closely — without actually privileging the experience of movement. Its televisual framing is designed to reveal to viewers that they can have strong responses to the ways dancing bodies are theatrically imbricated within a larger choreography of elements traditionally understood to play supporting roles.

\section{The Pedagogy of SYTYCD}

The duet for Melissa Sandvig and Ade Obayomi was choreographed by Tyce Diorio, but it was not the first element of the presentation that studio and television audiences saw. As is customary for the show, the piece was introduced by a "package" that included edited studio clips of the dancers rehearsing, interspersed with shots of them talking to the camera about what they learned and how they experienced the process leading up to performing the dance before the judges. Whereas in live concert dance program notes can provide the audience with additional context or framing for what appears onstage, the televised format of SYTYCD imposed a carefully constructed context on its viewers before they saw what was introduced as "an emotional contemporary piece." Diorio explained why he had created the duet: "I felt compelled to talk about breast cancer," referring to a friend diagnosed with the disease. ${ }^{2}$ In the clips of Sandvig and Obayomi rehearsing in the studio, they told the television audience how they wanted to be perceived. Sandvig said that the dance was difficult because it was "not about our steps and how we're dancing. The hardest part is portraying that message." Her statement begs the question: Was Sandvig worried about portraying the message of breast cancer awareness or worried about how she and her partner would be judged within the competition framework on a dance piece that happened to be based on that theme? The judges picked up on the quote, reinforcing an underlying tension between the dance and its "message." Executive producer Nigel Lithgow championed Sandvig's cause: your "routine," he said, was not one to be judged "on your dance or your steps." Another judge, choreographer Mia Michaels, agreed: "There is really nothing else I can say because it's not really about the dancing, although it was a perfect portrait of what was being said."

I want to think with this moment, rather than about it. Here, the dance is clearly less a matter of movement alone than of the very explicit shaping of spectator experience that occurs in

2. All quotations in this paragraph are from So You Think You Can Dance, season 5, episode 18 (SYTYCD 2009). 
relation to it: the extended choreography of the entire presentation, from the introductory clips through the routine and into the judges' responses. I know I risk being unfair in asking such a quickly choreographed, commercially oriented dance and its televised framing of spectatorship to stand as an interlocutor for dance studies, but, at the same time, this particular dance-that-isnot-about-dance was almost nominated for a 2010 Emmy for choreography. It was seen, on its first airing, by 7.3 million viewers, and was restaged during the season finale for a 3,000-person live audience and 7.8 million television viewers. ${ }^{3}$ With its conservative artistic and social inclinations, the show represents a very real part of what dance is for most people in the US. I could simply write off the segment as mediocre choreography, or as part of the manipulative American culture industry whose marketing of easy sentiment Theodor Adorno so ardently criticized. But that does not sit well with me, in part because doing so negates the very real fact that, along with the influential judges whose spectacles of experience shaped the televised version of the dance, people I know also admitted, when I asked, that they too cried.

This segment is emblematic of the ways in which SYTYCD trains audiences in affective dance spectatorship at the same time as it calls attention to the theatricality of dance as an art form. Such pedagogy takes on a certain urgency within the context of the program because the judges do not so much judge as guide the amateur public - on whom the competition ultimately hinges. While much has been made in media studies about reality television as a training ground for various (questionable) models of democracy, SYTYCD functions in a more specialized sense: SYTYCD's pedagogy inverts several hierarchies of apprehension that tend to be taken for granted. The way it teaches its audience to view dance in terms of extended choreography can help us to consider the complicated means through which audiences relate to the layered framings of all dance performances.

The first lesson SYTYCD imparts is the one I have just demonstrated with the responses to Sandvig: despite the spectacles of embodiment that punctuate the events, movement on SYTYCD rarely exists for its own sake. Although the routines are constructed of mostly extraneous actions in a stricter choreographic sense, the packages and the judges' responses help audiences to assimilate that hyperkineticism into a particular "story" in order to respond to it. These narratives must sell, because the verbalized stories have become increasingly elaborate over the show's many seasons. In the case of this performance, the generic cancer narrative was superimposed over the staged story of a man and woman — the duet - that unfolded in the actual dance, reinforced by a third referent, the personal cancer story added to it each of the three times it appeared on SYTYCD: first, when Diorio told the cameras that he had made it for his friend with breast cancer; next during the season finale when Diorio announced that the friend had "just" been declared cancer-free; and finally when it was performed on the first UK SYTYCD six months later. On that episode, Lithgow explained that the choreographer had to rush back to New York because his mother was ill with pancreatic cancer.

The second aspect of SYTYCD's pedagogy concerns attending to the dancers' labor. Because the show, like many reality shows, promotes a serialized investment in the dancers as people, ${ }^{4}$ the act of performing becomes visible as performance when they take on character types within the stories of the dances. One of the avid viewers I spoke with, a video game designer, told me that she was surprised how little she cared when dances were restaged in later seasons. Although they may have been affectively charged for her when she was involved in the show's narrative development of the dancers as people, the choreography did not carry emotional weight when she saw the pieces repeated by the same dancers but outside of that arc. In other words, the dances were effective when the narrative frame of the show's challenges was clearly fore-

\footnotetext{
3. See Nielsen (2009a and 2009b). The final result was decided by 21.6 million votes.

4. See Jenkins on American Idol and fan investment (2006:59-79). However, this is complicated on SYTYCD, where the contestants are often professional dancers, alongside being "regular" people.
} 
grounded, so that the viewer could carry her involvement with the dancers into the dances they performed.

The third element of the show's didactic structure, one that is conspicuously all but absent in this particular segment, is that judges tend to discuss how dances might excite audiences. They often defamiliarize the act of aesthetic judgment by commenting that certain codified styles of dance, music, costuming, and lighting solicit votes more easily than others. In this way, they influence the voting by asking viewers to witness how their relationship to the dances is structured by these spectacular elements, a reflexive strategy that reinforces the competition's overarching goal of selecting America's "favorite" — as opposed to a more "objective" superlative, such as "best" - dancer.

\section{A Reminder about Dance, Illness, and Embarrassment}

The placement of this particular segment is important in the season's episodic trajectory: of the four remaining women, Sandvig was probably the weakest contestant, but her duet solicited such a strong voter reaction that a more talented female dancer was eliminated, a charismatic and versatile performer who was a favorite of the professional judges. (The reprieve was short lived; Sandvig was voted off the following week.) To take the dancers and judges at their word, that the piece was not about the dance — although sweat was certainly expended — suggests a precarious ethical situation in which the outcome of the dance competition was affected by an audience response elicited through something other than movement. In online forums devoted to the show, it became clear that for many in the audience, their relationship to the duet was informed by an intimacy with the familiar narrative, as was Michaels's, who wished she had been as "strong for [her] daddy" as Obayomi was in "being there" to catch and lift Sandvig. And yet, in practice, the disjunction between the weakness of an actual breast cancer victim and Sandvig's physical prowess recalls Sally Banes's discussion of the contradictions ballerinas often enact between the plot they are conveying and the physicality their performances demand (1998:8-11). Although Banes means to complicate theorizing gender in staged representations, her interest in the conflicts between plot and performance points toward the many gaps and disjunctions that structure the experience of watching dance.

Recall the controversy surrounding Bill T. Jones's 1994 piece Still/Here. I am not talking about Arlene Croce's critique of the ethics of what she called "victim art" so much as the responses by Marcia Siegel and Ann Daly regarding the too-easy elision of difficult life stories with dancing that was not particularly difficult to watch. Daly found the "formalist patina" of Jones's dance problematic; she thought it rendered the dance "too tidy to be affecting." She pointed out the "deeply ironic tension between the abundant health of the dancers and the physically ailing workshop participants whose bodies they are representing" ([1996] 2002:63). Similarly, Siegel raised concerns about Still/Here's "mainstream aura," its similarity to "the mass fictions of TV and advertising," which lent an ease to the act of watching. She found "something inappropriate about its flashy visual investiture, its snappy timing, its ruthless editing of the tapes, its slick, accomplished dancing. It left the audience screaming with delight instead of pausing for reflection" (1996:69). Underlying the responses by Siegel and Daly is the implication that, although Jones's piece was not the "victim art" that Croce imagined it was, it certainly was not untainted. It was as though, for Siegel and Daly, there was something embarrassing about the fact that a piece about terminal illness was made in and from dance that was both too self-aware and not aware enough. These critics' ideal Still/Here would have involved a more challenging formal apparatus through which such charged material could emerge. ${ }^{5}$ This they

5. In many ways, the problem with Still/Here seemed to return to the illness narrative functioning as a kind of genre story. However, as Petra Kuppers points out, alternative representational strategies might be more suited to dealing with experiences of pain and medical intervention. She cites Angela Ellsworth's 1998 Hermanderby (2007:66- 

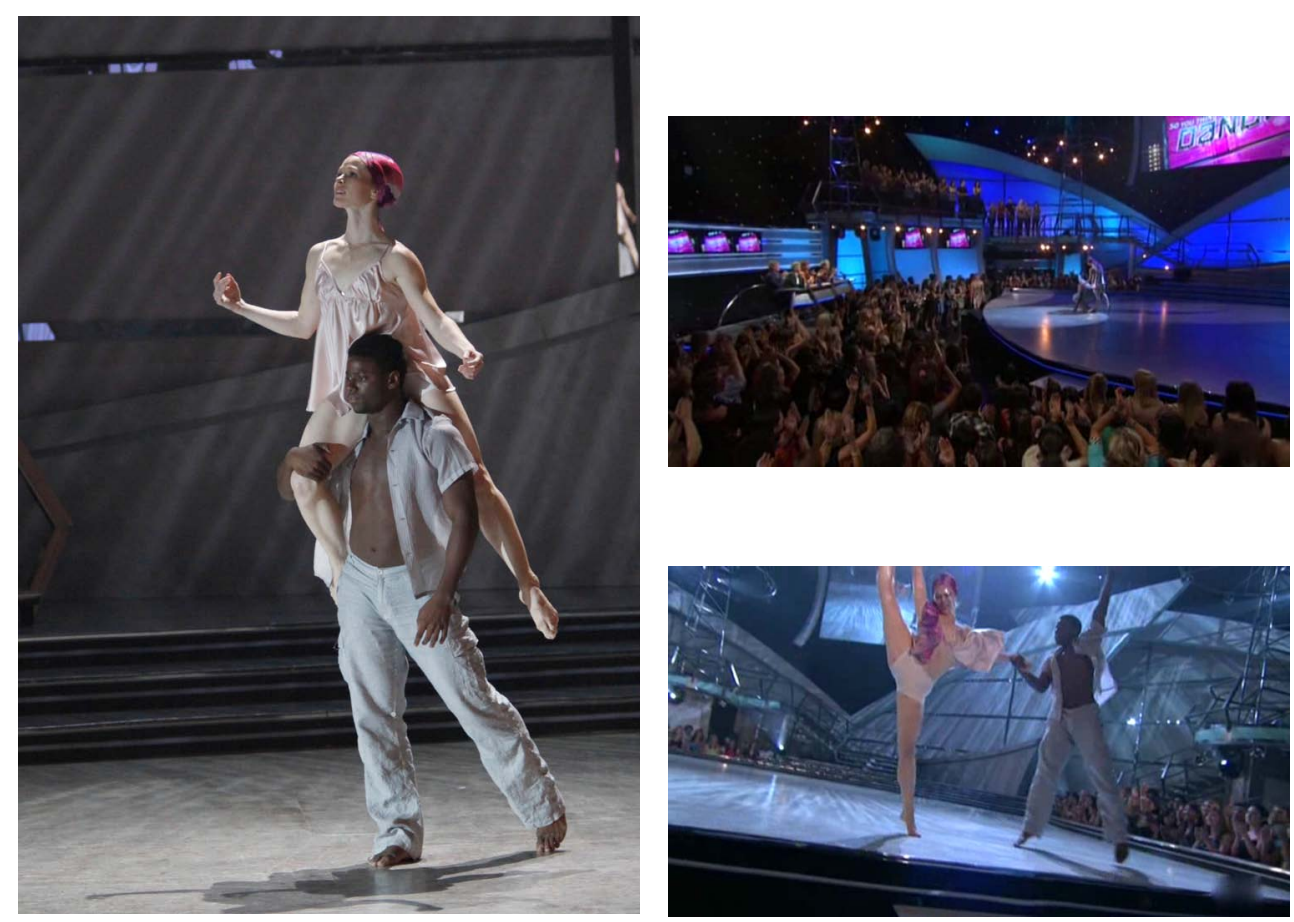

Figures 5-7. Compare the publicity still of This Woman's Work performed by Sandvig and Obayomi (fig. 5, courtesy of FOX from So You Think You Can Dance, season 5, episode 18), which suggests a more traditional theatrical staging, to two images of the routine as televised (figs. 6 and 7), including studio audience, lighting, judges, and video screen. (Screen grabs courtesy of Kate Elswit, with permission of FOX)

compared to the piece's actual realization, which they suggested followed a structure that, like the evening news, presented bad stuff as glossy spectacle.

Both Siegel and Daly were so convinced that there was something disingenuous about the showmanship of Still/Here - with more capacity to appeal than to offend, as Siegel put it — that they could not ask questions about the kinds of engagements that such a piece successfully promoted. Their assumptions about the sort of dance that might be affective, and therefore politically efficacious, blinded them to another possibility that is visible within the debate. At the end of her essay, Siegel admits sympathy with Croce's objection to the "machinery of promotion and manipulation," writing that it is hard to look at what is onstage "when you have previously been subjected to outrageous publicity, sympathy-eliciting personal disclosures, inside information about what went into the dance" (67). But what if all of that theatrical machinery - including the construction, the commerce, the self-awareness - is what is onstage? What if its visibility has the potential to elicit strong feeling? This certainly seems to be the case for SYTYCD.

In Stage Fright, Animals, and Other Theatrical Problems, Nicholas Ridout suggests that the political value of theatre, in contrast to performance, can be found in theatre's constitutive failure: "our discomfort with it, its embeddedness in capitalist leisure, its status as a bourgeois pastime" (2006:3-4). For Ridout, the theatrical "accessories" that may be unwanted because they mark exactly such a relationship are in fact vital to audience experiences. Ridout's observations

73), but the Burning workshops (2008-09) by her own Olimpias collective also artistically reimagine cancer outside of medicalized discourse. 
on the affects that result from such compromised encounters begin by juxtaposing the "guilt" of theatre's representational techniques with performance's claims to "innocence" in insisting upon its unmediated nature. Following Ridout's proposition in relation to dance-a medium that is often just as extravagant as theatre - offers a possibility for thinking about potential outcomes of the dance encounter, beyond the innocence that is often associated with dance's bodily presence. What if "tear-jerker" dances like Still/Here or the STYTCD segment move spectators (or fail to move them) precisely because of the relationship they establish between the overt theatrical presentation that audiences are trained to disregard, and the process of attaching that presentation to the threat of death? What if spectators respond to the gaps produced at the conjunction of the artistic form and the traumatic life it references? What if those watching become involved in the relation between the performances and their own literality?

\section{Feeling the Extended Choreography}

In Pictures and Tears: A History of People Who Have Cried In Front of Paintings, James Elkins lists the many reasons that tears might emerge in relation to art. One is disappointment or, more precisely, unfulfilled expectation. A promise built up, but not met (2001). Me, I get anxious watching that eight-minute sequence from SYTYCD. My neck itches when I hear the uninterrogated rhetorical maneuver of using terminology for speech ("talking," "saying," e.g., "the dance talks about...") in relation to a series of movements that can obviously say very little without verbal supplement. There is something suspicious in the overdetermined explanations; the choreographer, dancers, and judges are forcing the issue by directing viewers' associations between the movement and the politics it means to invoke, as though the dance alone might not get there. The undifferentiated wriggling, which is to say the choreography, is separate from the story, but would be entirely unintelligible without it. The bulkiness and heft of the genre narrative threatens to foreclose the possibility of engaging with the movement, which is crushed under its weight. The crying judges make me too aware that my eyes are dry. I have tried watching the sequence on mute to strip away the song's timbre and lyrics from the movement, but the physicality remains awkward and confusing. Like the too-familiar story, the recognizable technical basis of the dance makes it easy to watch, while at the same time it appears profoundly strange against the bad stuff that frames it. There is something embarrassing about the abrupt arabesques and rond de jambes and pointed feet, the repetitive and vigorous flexion and extension of the couple's spines. The jumps may coincide with musical climaxes, but they disperse rather than focus my attention. The duet's physical prowess sits uncomfortably with the difficulty of the dance's topic. And yet, it is in the moment that Sandvig fails to straighten her leg to full extension on a développé that I become aware of the gap between the melodrama of the character's story that is asking for pathos, attention, and votes from a television audience on the one hand, and on the other, the dancing in which I struggle to perceive anything...vulnerable? ...cancerous?

In the introductory clips, neither Sandvig nor Obayomi declare any personal associations to cancer survivors, but this lack of a personal story allows them to take on the roles Diorio has "written" for them. The healthy body of the pale, crying, ballet-trained dancer (who appears particularly striking against the muscular, black partner who lifts her) accords with the illness narrative of the choreographer's invisible friend more explicitly than do the bodies of the Still/ Here dancers. ${ }^{6}$ And yet, as in my friend's description of rewatching the same routines by the

6. In Still/Here, film projections of testimony from the national workshops with people facing life-threatening illnesses were primarily distanced from the contemporary dancers by the gap between the televised and the live. And yet, in practice, despite the distance established by this separation between the mediated subjects and their live onstage representatives, and by Jones's refusal to refer to AIDS in any encounters that might shape audiences' understanding of the piece, Still/Here was complicated by the conditions of its creation: Jones's partner Arnie Zane's death from complications related to AIDS. 
same dancers again in later seasons, that pairing is actually not the type of thing SYTYCD is training audiences to see. Instead, the show wants viewers to be aware of tensions, like those between the dancers as people and the dance roles they perform. ${ }^{7}$ The extended choreography demands that television audiences develop an investment in witnessing the performance task itself, with all of its representational complications.

Priya Srinivasan enumerates the complexities of this kind of layered spectatorship in her essay "A 'Material'-ist Reading of the Bharata Natyam Dancing Body: The Possibility of the "Unruly Spectator'" (2009). Srinivasan describes watching a Bharata Natyam performance while being distracted by reminders of the "labor of many bodies, techniques, and material objects that produce the body onstage," even though those labors have been written out of the history of the form (2009:54). She worries about the sweat that gathers on the silk sari, a loose bell on which the young performer might (and then does) cut her foot, and the possibility that the dancer's blood might ruin the costume. Through these objects, Srinivasan demonstrates how it is possible to develop strong feelings in relation to the accoutrements that allow the dancer's performance to come into being in the world at the same time as they bring the outside world onto the stage.

This is also an embodied experience for Srinivasan. But the encounter shifts when she sees, for example, the dancer as a person who needs to walk away from the performance capable of repeating it again the next day. The register changes. Srinivasan offers critical observations that are grounded in experiences of strong feeling. And yet that feeling is directed toward the labor of dance's (re)presentation, which, in turn, calls attention to the labor of spectatorship. If what is understood as spectacle relies on an idealized structural conjunction of vehicle and meaning, Srinivasan demonstrates how the inevitable failure of that system leaves vulnerable points through which spectators may enter. In other words, audience reactions to dance performances can be produced not only through the movement of the dancers, but also through the gaps that surround dance's appearance and demand attention or-dare I say - even love. These gaps appear in Srinivasan's essay not only between the teenage dancer and her mythic role, but also between storytelling and rote movement, between the "fictive history" of the form and its present reconfiguration, and between the beautiful costume and how its silk is embedded within global capitalism.

Attending to such gaps refigures the act of dancing as a process that builds a structure to solicit engaged meaning-making, and what better paradigm than SYTYCD with its extended stories, virtuosic performers, theatrical spectacle, and near-instant feedback? The allegedly passive television audience here models the active work of viewing. The show trains its viewers in the skills of spectatorship using the suggestion that audiences might form relationships with dance by witnessing themselves settling into such gaps and thereby closing them. The carefully engineered double narratives - of the danced stories and of the individual dancers attempting, and sometimes failing, to dance at a high technical level — develop the viewers' awareness of the challenge of maintaining both simultaneously. The pre-performance segment of clips assists spectators by foregrounding dance and staging techniques, such as showing rehearsals in which the dancers fail at the more difficult maneuvers, so that the physical challenges of executing these moves are recognized when they appear as part of longer dance sequences on the competition stage. In this way, any feeling response is closely related to the experience of negotiating

7. In some ways, this more precise witnessing of myself within the gap between the dancers as people and as performers is what Maaike Bleeker writes about when she tries to account for the relationships and gaps between the body seeing and the body seen in Visuality in the Theatre: The Locus of Looking (2008). Conspicuously, Bleeker attends to the question of witnessing though a selection of practices that use re-theatricalization as an artistic strategy, under the assumption that heightening the visibility of the structuring mechanisms can enhance the act of witnessing. 
connections between the over-the-top "story" of the dance and the effort it takes to physicalize it onstage, rather than one undermining the other.

This is how SYTYCD trains its audiences in affective spectatorship. The show reveals the way the logistics of representation that structure dance performances establish - through their visibility rather than their absence - viewing relationships. It makes explicit a set of possibilities for personal engagement beyond the experience of movement. Recognizing this other pedagogy of watching, however, requires a bit of unruliness, not only as a spectator but also as a scholar willing to learn from what Lauren Berlant would call "the counterpolitics of the silly object" (1997:12).

\section{Postscript}

Six months later, the United Kingdom presentation of Diorio's dance repeated the three-act format, including a more restrained version of the tearful responses. The opening package included interviews of hometown folk expressing support for the dancers. In the brief studio footage, Charlie Bruce, the young jazzarina who ultimately won the season's competition, faced the camera in a large faux-fur collar to preface the affective solicitation of the dance itself. She said the piece "really really makes you want to cry. It takes me to a whole 'nother level. I think when we perform this, my whole family will be getting the box of tissues out. I think they are going to be in floods of tears and very proud of me on Saturday night." ${ }^{\prime}$ The duet and judging followed. Whereas the US version of the piece had cast the oldest dancer on the show's "top 20" (she was 29) for this duet, together with the strong black "gentle giant," as one judge called Obayomi, the UK version paired a bubbly 19-year-old with a young male contemporary dancer with bleached hair. Although it was never made explicit for UK viewers that this dance "routine" had been performed before, in the age of YouTube, many viewers engaged with these dancing bodies through their predecessors, treating the choreography as a kind of script through which multiple interpretations could be compared. On online discussion boards, the general consensus seemed to be that Sandvig's performance was technically imperfect, and yet that meant that she was able to convey the charged material with more feeling than Bruce, whose legs went far higher.

Perhaps the issue was not only the way in which the technical imperfection called attention to the labor of dancing, but also that their performances had been set up differently: Although the UK presentation maintained Diorio's same central duet, the extended choreography changed, causing a narrative revision to what audiences saw in the piece and how they responded to it. Even before Bruce presaged her family's tears, the package showed clips of her partner Robbie White's hometown support: posters with his smiling face, "Vote Robbie" spelled out in a relief of sausage links, and a good-luck cake topped with a fondant scene of a blond dancing figure in front of a television screen reading "SYTYCD." Whereas the US version had shown only the studio, with the dancers and choreographer describing the dance's "story" and then each dancer discussing the challenge of performing it in a competition setting, the UK version used the package to promote the narrative of the program as a whole. Presuming the impact of the dance based on the previous US iteration, the producers of the UK version forgot to teach audiences how to watch the duet. Instead, they skipped ahead to focusing on the dancers' potential to use the choreography as a platform for success. They released their hold on the representational tensions of dancing that story, displacing the affective potential of theatricality and its inviting gaps. 


\section{References}

Banes, Sally. 1998. Dancing Women: Female Bodies on Stage. London: Routledge.

Berlant, Lauren. 1997. The Queen of America Goes to Washington City: Essays on Sex and Citizenship. Durham, NC: Duke University Press.

Bleeker, Maaike. 2008. Visuality in the Theatre: The Locus of Looking. Hampshire, UK: Palgrave Macmillan.

Daly, Ann. 1992. "Dance History and Feminist Theory: Reconsidering Isadora Duncan and the Male Gaze." In Gender in Performance: The Presentation of Difference in the Performing Arts, ed. Laurence Senelick, 239-59. Hanover, NH: University Press of New England.

Daly, Ann. (1996) 2002. "Dancing The Unsayable.” In Critical Gestures, 60-63. Middletown, CT: Wesleyan University Press.

Elkins, James. 2001. Pictures and Tears: A History of People Who Have Cried in Front of Paintings. New York: Routledge.

Foster, Susan Leigh. 2008. "Movement's Contagion: The Kinesthetic Impact of Performance." In The Cambridge Companion to Performance Studies, ed. Tracy C. Davis, 46-59. Cambridge: Cambridge University Press.

Jenkins, Henry. 2006. Convergence Culture: Where Old Media and New Media Collide. New York: New York University Press.

Kuppers, Petra. 2007. The Scar of Visibility: Medical Performances and Contemporary Art. Minneapolis: University of Minnesota Press.

Lepecki, André. 2006. Exhausting Dance: Performance and the Politics of Movement. New York: Routledge.

Massumi, Brian. 2002. Parables for the Virtual: Movement, Affect, Sensation. Durham, NC: Duke University Press.

Nielsen. 2009a. "Primetime Broadcast Ratings: July 22, 2009.” Nielsen Wire, 23 July, http://blog.nielsen .com/nielsenwire/media entertainment/primetime-broadcast-ratings-july-22-2009/ (10 September).

Nielsen. 2009b. "Primetime Broadcast Ratings: August 5, 2009.” Nielsen Wire, 6 August 2009, http://blog .nielsen.com/nielsenwire/media entertainment/primetime-broadcast-URL....ratings-august-5-2009/ (10 September).

Ridout, Nicholas. 2006. Stage Fright, Animals, and Other Theatrical Problems. Cambridge: Cambridge University Press.

Siegel, Marcia B. 1996. "Virtual Criticism and the Dance of Death." TDR 40, 2 (T150):60-70.

Siegmund, Gerald. 2008. "Zur Theatralität des Tanzes." In Tanzforschung und Tanzausbildung, ed. Claudia Fleischle-Braun and Ralf Stabel, 28-44. Henschel.

Srinivasan, Priya. 2009. "A 'Material'-ist Reading of the Bharta Natyam Dancing Body: The Possibility of the 'Unruly Spectator.'” In Worlding Dance, ed. Susan Leigh Foster, 53-75. New York: Palgrave Macmillan.

Thomas, Helen. 2003. The Body, Dance and Cultural Theory. New York: Palgrave Macmillan.

To view supplemental media related to this article, please visit www.mitpressjournals.org/doi/suppl/10.1162/DRAM_a_00148 